\title{
When Ideas Have Sex: The Role of Exchange in Cultural Evolution
}

\author{
M.W. RIDLEY \\ Blagdon Hall, Newcastle, NE13 6DD, United Kingdom \\ Correspondence: mwridley@gmail.com
}

\begin{abstract}
Human economic and technological progress has been dominated for the last 100,000 years by natural selection among variants of cultures, rather than among variants of genes. Evidence suggests that cultural evolution depends on exchange and trade to bring together ideas in much the same way that genetic evolution depends on sex to spread genetic mutations, or in the case of bacteria, on horizontal gene transfer. When starved of access to a large "collective brain" by isolation from trade and exchange, people may experience not just less innovation, but even regress. The capacity for ideas to have sex on the Internet is likely to accelerate cultural evolution still further.
\end{abstract}

According to Richerson and Boyd (2005), cultural evolution can be a Darwinian process but not a genetic one, proceeding largely by the selective survival and transmission of habits, tools, and ideas. Of course, culture can select genes to coevolve, as in the selection on two separate occasions of mutations for the adult digestion of lactose following the domestication of cattle (Tishkoff et al. 2007). But the chief reason that modern society is different from Paleolithic society is down to extensive and cumulative cultural change, rather than extensive and cumulative genetic change. The entities that compete for survival in cultural evolution are variants of culture. Selective survival happens because human beings copy one another in learning such things, and occasional fortuitous improvements in relatively faithful copying can be sufficient to allow Darwinian natural selection to occur. There is less intentionality in history than human beings like to assume.

This is not a new idea. The Austrian economist Friedrich Hayek (1960) wrote that in social evolution, the decisive factor is "selection by imitation of successful institutions and habits." The evolutionary biologist Richard Dawkins (1976) in the 1970s coined the term "meme" for a unit of cultural imitation. The economist Richard Nelson in the 1980s proposed that whole economies evolve by natural selection (Nelson and Winter 1982). But until recently, Darwinian cultural evolution had not been formally modeled. Now it has been, and it is clear that the parallels with genetic evolution are closer than might have been expected (Henrich et al. 2009).

Copying and innovation in culture are thus equivalent to replication and mutation in biology. Tribalism and language divergence are equivalent to speciation (Pagel and Mace 2004), whereas functional adaptation - fitting form to function - is rampant in cultural evolution, as are Red Queen arms races in which advantages prove to be transient. Differences exist between cultural and genetic evolution, but modeling shows that they do not prevent Darwinian consequences. For example, the fact that muta- tion is not purely random in culture, but is sometimes intended as deliberate improvement, need not alter the outcome as long as there is a degree of random experiment (Henrich et al. 2009). In any case, the history of technology shows that innovation is a far more incremental, bottomup, and trial-and-error process than the "heroic inventor" stories we tell one another - or to the Patent Office (see, e.g., Basalla 1988).

The steam engine thus progressed through the designs of Denis Papin to Thomas Savery to Thomas Newcomen to James Watt to Richard Trevithick to George Stephenson by relatively small, incremental steps, by "descent with modification." Yet, at each stage, the heroic inventor exaggerated the revolutionary and unfathered nature of his breakthrough in order to claim either intellectual kudos or a lucrative legal monopoly. In two cases-Thomas Savery and James Watt-aggressive prosecution of a vaguely worded patent on the use of steam enabled the inventor to slow down and set back the further improvement of the entire technology, in Watt's case to a dramatic degree (Boldrin and Levine 2007).

Another difference between cultural and biological evolution is that much cultural evolution occurs by group selection-in Darwin's words, "a tribe... always ready to aid one another, and to sacrifice themselves for the common good, would be victorious over most other tribes; and this would be natural selection" (Darwin 1859). But this makes no great difference either. Natural selection can work well among groups, provided groups have a high enough death rate, as history shows they clearly do: Witness the frequent extinction of languages. It so happens that the conditions for group selection in genetic evolution are rare, except in the special case of groups of close kin.

Here I want to explore the parallel between sex (genetic exchange) and trade (cultural exchange), in order to provide a preliminary test of the hypothesis that the invention of exchange caused a sudden acceleration of cultural evo- 
lution in the Middle Stone Age and therefore largely explains why one African hominin subspecies exploded into ecological dominance in a way that other hominins did not. This notion is not wholly original. Like all good ideas, it has evolved by descent with modification, its immediate ancestors being Ofek (2001), Henrich (2004), Richerson and Boyd (2005), and Seabright (2005), not to mention Smith (1776).

\section{HORIZONTAL EXCHANGE}

Sexual reproduction accelerates the fixation of beneficial mutations and the elimination of harmful ones through recombination, the phenomenon known as Muller's ratchet (Ridley 1993). It therefore helps to make the evolution of traits cumulative: A less-fit lineage that nonetheless has a single beneficial trait can bestow it on a fitter lineage through sex. The acquisition of new traits is accelerated by the fact that through sex, each individual in effect draws upon the entire gene pool of the species and therefore has access to a wider source of genetic innovations than are available in its vertical lineage. Asexual exceptions turn out to prove the rule; i.e., they find other ways of indulging in genetic exchange. Bdelloid rotifers, for example, have experienced massive horizontal gene transfer between species and kingdoms, which explains how they have achieved diversity and fitness without having sex for 80 million years (Gladyshev et al. 2008).

Such exceptions aside, however, animals and plants are generally limited to genetic exchange within the species, which balkanizes evolution of multicellular creatures: Much as some mammals might benefit from having ultraviolet vision and some insects might benefit from having mammary glands, the requisite genes are inaccessible to them. No such constraint applies to the microbial world, where it is now apparent that adaptation to new environments (such as the human deployment of antibiotics) occurs through the promiscuous swapping of genes between "species" of bacteria; indeed, that bacterial "species" are almost more like transient "firms" of genes than closed species.

Exchange has the same role in cultural evolution. Plenty of animals show vertically transmitted culture: Killer whales, chimpanzees, crows, and dolphins all show the ability to pass on local traditions to their young. But in none of these species is culture cumulative. The reason for this is vertical transmission equivalent to heredity in an asexual species. A chimpanzee can acquire the culture of only its own group, not that of other groups. Not only do human beings tend to learn skills from prestigious individuals other than their parents (Henrich 2004), but human culture is transmitted horizontally as well as vertically between groups through exchange and trade. The effect is that a human being draws upon a vast "gene pool" of cultural inventiveness encompassing almost the entire species. I suggest that the invention of exchange was the trigger for the explosion of human numbers, range, and ecological impact that happened in the past 100,000 years or slightly more.

\section{THE COLLECTIVE BRAIN}

Human beings are seemingly more intelligent than other animals, but this alone cannot explain the "human revolution" of the past 100,000 years when a scarce African ape at the mercy of its environment became a global species that commandeers $22 \%$ of the planet's natural primary productivity (Haberl et al. 2007). The problem is not just that big hominin brains and the capacity for language appear to be much more than 100,000 years old, with no evidence of a threshold reached or a switch thrown at a particular point, but more particularly that human ecological success is not an individual phenomenon. It is a collective phenomenon; i.e., modern technology, science, and culture are the aggregate product of millions of brains, none of which knows how to achieve them. As the economist Leonard Read put it in his essay "I, Pencil," even an ordinary pencil is made by millions of people, from loggers in Oregon and graphite miners in Sri Lanka to coffee bean growers in Brazil (who supplied the coffee drunk by the loggers). "There isn't a single person in all these millions," Read concludes, "including the president of the pencil company, who contributes more than a tiny, infinitesimal bit of know-how" (Read 1958). Knowledge, said Friedrich Hayek, "never exists in concentrated or integrated form but solely as the dispersed bits of incomplete and frequently contradictory knowledge which all the separate individuals possess" (Hayek 1945). There was a point in human history when this became true for the first time.

Cultural and technological complexity depends critically on population density (Simon 1996). This is evident at every scale and in every time period - from the complexity and inventiveness of modern cities contrasted with the simplicity of modern pastoralists; from the richness of early agricultural societies to the simplicity of hunter-gatherers; from the sophistication of dense huntergatherer societies that lived on rich marine resources in the Pacific Northwest to the simple technologies of sparse Australian aboriginal societies. The denser a human population becomes, the greater the chance that it will show rapid cultural innovation. Pet-grooming salons and sushi restaurants are found in large cities, not remote rural settlements. This population-density effect is not true of other species.

There is increasing interest among archaeologists in explaining the sporadic and ephemeral nature of Middle Stone Age technological advances by reference to demographic factors (Powell et al. 2009; Richerson et al. 2009). Two sudden and temporary efflorescences of new technologies in Southern Africa $~ 70,000$ years ago both seem to coincide with population expansions, as does the explosion of innovation that happened in western Eurasia 40,000 years ago (Jacobs and Roberts 2009).

Conversely, where population falls or is fragmented, cultural evolution may actually regress. A telling example comes from Tasmania, where people who had been making bone tools, clothing, and fishing equipment for 25,000 years gradually gave these up after being isolated by rising sea levels 10,000 years ago (Henrich 2004). Henrich argues that the population of 4000 Tasmanians 
on the island constituted too small a collective brain to sustain, let alone improve, the existing technology. Tierra del Fuego, in a similar climatic and demographic position, experienced no such technological regress because its people remained in trading contact with the mainland of South America across a much narrower strait throughout the prehistoric period. In effect, they had access to a continental collective brain.

\section{DID NEANDERTHALS EXCHANGE?}

I therefore argue that the reason the technology used by Eurasian Neanderthals, with their big brains and probable linguistic skills (Krause et al. 2007), did not show significant evolution or local traditions was that Neanderthals did not engage in exchange. Almost all Neanderthal tools have been found - so far-within an hour's walk of their likely site of origin (Stringer 2006), whereas it is characteristic of African-origin hominins from at least 120,000 years ago that artifacts travel long distances, probably by trade. For example, shell beads in Algeria and obsidian tools in Ethiopia dating to more than 80,000 years ago have been found more than 100 miles from their likely maritime and volcanic source, respectively (Negash et al. 2006; Barton et al. 2009). In more recent times, stone axes manufactured by the Kalkadoon at a site called Mount Isa in northern Australia found their way across half the continent before western contact. Such trade networks greatly enlarge the collective brain at the disposal of each individual by giving him access to material and ideas from a wide area and a large population (Sharp 1974).

In contrast, even 30,000 years ago, European Neanderthals apparently lacked the habit of trading between groups, and simulation shows that this alone would have rendered them vulnerable to extinction in the face of competition from trading Cro-Magnons, because they were unable to survive temporary or local shortages (Horan et al. 2005). In the words of Adler et al. (2006), "we hypothesize that it is the development and maintenance of larger social networks, rather than technological innovations or increased hunting prowess, that distinguish modern humans from Neanderthals in the southern Caucasus."

There is, of course, a plethora of other candidates to explain human success: upright stance (which freed the hands), opposable thumbs, tool use, grandparental care, fire and cooking, large brains, foresight and planning, and, of course, language. The problem with each of these explanations, however, is that it occurs too early in the story or applies to other species as well, especially the Neanderthals. Cooperative rearing, for instance, is shared by many primates and is probably an ancient feature (Hrdy 2009). Cooking undoubtedly made the evolution of large brains possible (Wrangham 2009) but may have begun with Homo erectus. The Neanderthals stand as a powerful reminder that it is possible for a hominin to be upright, dextrous, tool-using, cooperative, fire-controlling, huge-brained, imaginative (Neanderthals buried their dead), and probably well spoken, yet still not experience rapid and cumulative cultural evolution leading to global ecological dominance. Exchange is the only feature of humanity so far described that arrives in the African lineage after the split with the ancestors of Neanderthals and coincides with takeoff.

\section{RICARDO'S MAGIC TRICK}

The cultural evolutionary process by which exchange both reduces risk and increases productivity or energy efficiency has long been known to economists. According to David Ricardo's Law of Comparative Advantage, building on the work of Adam Smith and others, exchange leads to specialization, which leads to both efficiency and innovation, which leads to further specialization, which encourages further exchange. If individual A has even a slight specialized knowledge of how to make or acquire object $\mathrm{X}$, and $\mathrm{B}$ has a slight skill in acquiring object $\mathrm{Y}$, then it pays them both for $A$ to make or get $2 X$ and swap one for one of B's 2Y. Remarkably, this is true even if A is better at acquiring both $\mathrm{X}$ and $\mathrm{Y}$ than is $\mathrm{B}$, as long as $\mathrm{A}$ finds $\mathrm{X}$ easier to get than $\mathrm{Y}$, and $\mathrm{B}$ finds $\mathrm{Y}$ easier to get than $\mathrm{X}$. So, for instance, an imaginary coastal fisherman can more easily catch two fish than a fish and a banana; his best way of getting a banana is to swap his extra fish for a spare banana picked by a trading partner living inland. As Ricardo famously put it, "England may be so circumstanced, that to produce the cloth may require the labour of 100 men for one year; and if she attempted to make the wine, it might require the labour of 120 men for the same time. England would therefore find it in her interest to import wine, and to purchase it by the exportation of cloth. To produce the wine in Portugal might require only the labour of 80 men for one year, and to produce the cloth in the same country might require the labour of 90 men for the same time. It would therefore be advantageous for her to export wine in exchange for cloth. This exchange might even take place, notwithstanding that the commodity imported by Portugal could be produced there with less labour than in England" (Ricardo 1817).

Once each individual is specializing in this way, each is bound to get better still at his own speciality. The more time the fisherman spends fishing, the better he gets at it, and the more time the inland trader spends banana picking, the better he gets at that. Charles Darwin, with scant evidence, presumed that this habit of specialization and exchange is long established in human beings: "Primeval man practised a division of labour; each man did not manufacture his own tools or rude pottery, but certain individuals appear to have devoted themselves to such work, no doubt receiving in exchange the produce of the chase" (Darwin 1871). Everything that has been discovered since then implies that he was right to the extent that exchange and trade long precedes other human inventions such as farming, money, or government. But it does not precede cumulative cultural evolution. The entire story of humanity since 100,000 BC has been one of sporadic and cumulative increases in specialization and interdependence through this Ricardian process, with many setbacks along the way. It is the very definition of modern prosperity to consume diverse goods and services in exchange for sin- 
gular and specialized production. The opposite - self-sufficient subsistence, in which consumption is no more diverse than production-is nowadays known as poverty.

No other animal does this. In those relatively few species where individuals do specialize - notably, social insects and other colonial creatures - the specialization is preordained by genes and environmental triggers; i.e., the number of castes in an ant colony does not increase indefinitely or change unpredictably with the life of the colony. Crucially, too, in social insects, the exchange and specialize bargain is struck between close kin, rather than between unrelated individuals. Indeed, the first and most extreme division of labor in all such species is the reproductive one, whereas reproduction is the only trait that human beings do not delegate to specialized individuals. (Not even in England do we leave breeding to a queen.) This balkanizes specialization within colonies. Human beings routinely practice exchange and specialization between strangers.

\section{EXCHANGE IS NOT THE SAME AS RECIPROCITY}

Note here that the kind of exchange required to make the Ricardian specialization engine work is emphatically not "reciprocity" of the kind that has long interested evolutionary psychologists and zoologists. Reciprocity is defined by Leda Cosmides and John Tooby (1992) as follows: "One party helps another at one point in time, in order to increase the probability that when their situations are reversed at some (usually) unspecified time in the future, the act will be reciprocated." In other words, it is the swapping of the same favor at different times. Such reciprocity is undoubtedly an important human social glue, as it is in other primates, cetaceans, some birds, and even vampire bats (Ridley 1996). It may indeed be the key to much cooperation. But it is not the same as exchange: the swapping of different objects at the same time. When an Australian gave a stone axe to his trading partner in return for a stingray barb, the bargain was simultaneous and heterogeneous, not delayed and homogeneous.

Cosmides and Tooby argue that reciprocity is harder to evolve than exchange because it requires trust during the delay between the favor and its return. Maybe, but it remains a fact that whereas homogeneous reciprocity is widespread if occasional in the animal kingdom, no other species has hit upon the trick of heterogeneous exchange between unrelated individuals (with the single exception of food-for-sex swaps between mates). "No man ever saw a dog make fair and deliberate exchange of a bone with another dog," said Adam Smith (1776). Sarah Brosnan's experiments with chimpanzees and capuchins have shown them to be quite capable of learning to exchange worthless tokens for food but incapable of learning to exchange valued foods for even more valued foods (Brosnan et al. 2008). Perhaps exchange is especially hard to evolve because it requires individuals to overcome the endowment effect, whereby individuals overvalue items in their possession relative to items that they do not yet possess (Kahneman et al. 1990; Brosnan et al. 2007).
Perhaps language is a prerequisite for exchange but not for reciprocity. Undoubtedly, language makes exchange easier, and it may be the case that human exchange could not begin until language had become sophisticated and subtle. This is, however, different from arguing that language itself causes cultural evolution. It is the power of language to assist exchange that drives cultural evolutionary acceleration, rather than the capacity for speech itself. Besides, if Neanderthals spoke but did not exchange - and it appears that they had genetic mutations possibly selected for by the use of language (Krause et al. 2007) - then widespread exchange is not a necessary consequence of language. Conversely, exchange can occur without shared language. Wrote Darwin of an encounter in Tierra del Fuego in 1834: "Some of the Fuegians plainly showed that they had a fair notion of barter. I gave one man a large nail (a most valuable present) without making any signs for a return; but he immediately picked out two fish, and handed them up on the point of his spear" (Darwin 1839).

\section{WHEN DID HUMAN EXCHANGE AND SPECIALIZATION BEGIN?}

The most universal, and probably oldest, form of human exchange and specialization is that between male hunter and female gatherer. The pattern of this sexual division of labor is highly variable but common to all humankind: In all hunter-gatherer societies yet studied, the two sexes use different foraging strategies but subsequently share the proceeds. This produces obvious Ricardian "gains from trade"; each sex can have access to both staple and reliable carbohydrates and unreliable but valuable protein. Each sex also gets access to the results of the other's specialized knowledge and skill. It is true that male foraging often looks as much like conspicuous display or the provision of a public good as individualized one-for-one exchange with individual females (Hawkes 1996), but this does not alter the consequence that males get access to (mostly) gathered food if they produce (mostly) hunted food, and vice versa.

If the sexual division of labor is the oldest form of heterogeneous exchange, perhaps it was the custom that "got us into the habit" of exchange (although it is also possible that the reverse is true and the sexual division of labor is a late application to family life of something learned through more general trade). But how old is the sexual division of labor? Glyn Isaac argued that it began with central-place foraging early in the story of the genus Homo, at least 2 million years ago (Isaac and Isaac 1989). Richard Wrangham (2009) argues that it follows naturally from the invention of cooking, which is a strongly gendered task that generates for females a valuable but visible and stationary product that is vulnerable to theft by males without protection, and that it dates back to the dawn of $H$. erectus more than a million years ago. On the other hand, Kuhn and Stiner (2006) argue that given the lack of evidence for "gathering" strategies in Neanderthal sites, the burden of proof is on those who would argue that Neanderthals had a sexual division of labor at all. This is 
not to deny the importance of cooperative foraging and food sharing in Neanderthal society but to suggest that Neanderthals of both sexes may have cooperated as hunters of megafauna, rather than foraged separately by sex for different foods.

Incidentally, dependent children do not explain the sexual division of labor well: They prove not to cramp the style of hunting females in many hunter-gatherers such as the Alyawarre (Bird and Bird 2008); even if female foraging is energetic, crèche-rearing and alloparentinge.g., by grandparents - can free most mothers to join in foraging activities (Hrdy 2009). If Kuhn and Stiner are right, the sexual division of labor could be a specifically African invention of less than 300,000 years ago, rather than an ancient invention of early hominin species. It may have triggered, or at least prepared the psychological way for, the continuous cultural evolution through natural selection of more and more specialization and exchange.

If so, exchange between genders would have been followed by exchange between other individuals within the band, which would have been followed by exchange between bands. This would have had to overcome the instant and violent hostility between bands that characterizes most nonhuman social primates (Hrdy 2009) and that still plagues the human species. Mechanisms for overcoming such hostility, such as smiling, abound in the human behavioral repertoire.

It is striking that both anthropological anecdotes and laboratory experiments point to the conclusion that simple barter begins between individuals in different groups, rather than anonymously between groups as a whole. Thus, each Yir Yoront stingray barb trader had a single stone axe trading partner whom he met at an annual trade festival (Sharp 1974), and undergraduates at George Mason University invent mutually beneficial trade between virtual villages (in "red" or "blue" items) on a oneto-one basis (Crockett et al. 2009). Collective trade begins with individual exchange.

\section{INTERACTION, NOT NECESSITY, IS THE MOTHER OF INVENTION}

The expansion of the human collective brain continues today. Humans devote their productive hours to ever more specialized "jobs," while accessing an ever more diverse range of consumption. In both activities, the individual draws upon a huge range of innovations made across a vast geographical and historical hinterland. A typical day in a modern office uses inventions made in India (zero), Palestine (iron), Asia Minor (money), Phoenicia (alphabet), Greece (science), Mesopotamia (writing), China (printing), Italy (credit), Mexico (maize), Peru (potatoes), Germany (aspirin), Britain (electricity), Massachusetts (telephone), California (semiconductors), Scandinavia (mobile networks), and Japan (Nintendo), to name just a few. Not one of these inventions is accessible to the inhabitants of North Sentinel island in the Andaman archipelago - the only people who continue to resist all contact with globalization; all are accessible to almost everybody else, at least in theory. This is not to pass judgment on what has happened, but to describe it. The collective nature of the human enterprise is now global, so that a cultural mutation in any part of the world can spread, if popular, to all other parts of the world, just as a genetic mutation in a flu virus can. The Internet is effectively a single planetary "agora" or marketplace in which ideas are experiencing sex, or at least horizontal transfer, on an unprecedented scale, allowing the spread, replacement, and fixation of innovations. In the 1980 s, computers were limited by their individual processing power. Today, they depend on shared and collective processing power: The same thing happened to human minds in the late Paleolithic.

\section{CONCLUSION}

The lineage of species leading to modern human beings experienced more than 2 million years of "normal" evolutionary change following the appearance of the first stone tools, i.e., technological change occurred no more rapidly than anatomical change. The basic design of the Acheulean hand ax typical of $H$. erectus lasted for more than a million years with very little change. Then suddenly, beginning probably between 300,000 and 100,000 years ago, there occurred a dramatic acceleration of technological change in Africa but not in other continents, accompanied by little or no change in anatomy. The timing and accelerating shape of this change does not fit the usual explanations based on some threshold or switch in human intelligence or language: it starts slowly, gathers pace, but peters out often. Instead, it is compatible with the explanation that intelligence had progressively begun to become a collective property shared by many specialized brains - a network effect. Cumulative and extensive cultural evolution was now possible because of the widespread pattern of exchanging objects, ideas, and services between individuals and the consequent specialization among them.

\section{REFERENCES}

Adler DS, Bar-Oz G, Belfer-Cohen A, Bar-Yosef O. 2006. Ahead of the game: Middle and upper palaeolithic hunting behaviors in the Southern Caucasus. Curr Anthropol 47: 89-118.

Barton RNE, Bouzouggar A, Collcutt SN, Schwenninger J-L, Clark-Balzan L. 2009. OSL dating of the Aterian levels at Dar es-Soltan I (Rabat, Morocco) and implications for the dispersal of modern Homo sapiens. Quat Sci Rev 19-20: 1914-1931.

Basalla G. 1988. The evolution of technology. Cambridge University Press, Cambridge.

Bird RB, Bird DW. 2008. Why women hunt: Risk and contemporary foraging in a western Desert Aboriginal community. Curr Anthropol 49: 655-693.

Boldrin M, Levine DK. 2007. Against intellectual monopoly. (Published online at http://www.dklevine.com/general/ intellectual/against.htm.)

Brosnan SF, Jones OD, Lambeth SP, Mareno MC, Richardson AS, Schapiro S. 2007. Endowment effects in chimpanzees. Curr Biol 17: 1704-1707.

Brosnan SF, Grady MF, Lambeth SP, Schapiro SJ, Beran MJ. 2008. Chimpanzee autarky. PLoS ONE 3: e1518.

Cosmides L, Tooby J. 1992. Cognitive adaptations for social exchange. In The adapted mind: Evolutionary psychology and the generation of culture (ed. JH Barkow et al.), pp. 163228. Oxford University Press, Oxford. 
Crockett S, Wilson B, Smith V. 2009. Exchange and specialization as a discovery process. Econ J 119: 1162-1188.

Darwin CR. 1839. The voyage of the beagle. Murray, London.

Darwin CR. 1859. On the origin of species by means of natural selection, 1st ed. Murray, London.

Darwin CR. 1871. The descent of man and selection in relation to sex. Murray, London.

Dawkins R. 1976. The selfish gene. Oxford University Press, Oxford.

Gladyshev EA, Meselson M, Arkhipova IR. 2008. Massive horizontal gene transfer in bdelloid rotifers. Science 320: 1210 1213.

Haberl H, Erb KH, Krausmann F, Gaube V, Bondeau H, Plutzar C, Gingrich S, Lucht W, Fischer-Kowalski A. 2007. Quantifying and mapping the human appropriation of net primary production in earth's terrestrial ecosystems. Proc Natl Acad Sci 104: 12942-12947.

Hawkes K. 1996. Foraging differences between men and women. In The archaeology of human ancestry: Power, sex, and tradition (ed. J Steele and S Shennan), pp. 256-275. Routledge, London.

Hayek FA. 1945. The use of knowledge in society. Am Econ Rev 35: 519-530.

Hayek FA. 1960. The constitution of liberty. University of Chicago Press, Chicago.

Henrich J. 2004. Demography and cultural evolution: How adaptive cultural processes can produce maladaptive losses-The Tasmanian case. Am Antiquity 69: 197-214.

Henrich J, Boyd R, Richerson P. 2009. Five misunderstandings about cultural evolution. Hum Nat 19: 119-137.

Horan RD, Bulte EH, Shogren JF. 2005. How trade saved humanity from biological exclusion: The Neanderthal enigma revisited and revised. J Econ Behav Org 58: 1-29.

Hrdy SB. 2009. Mothers and others: The evolutionary origins of mutual understanding. Belknap/Harvard University Press, Cambridge, MA.

Isaac GL, Isaac B. 1989. The archaeology of human origins: Papers by Glyn Isaac. Cambridge University Press, Cambridge.

Jacobs Z, Roberts RG. 2009. Human history written in stone and blood. Am Sci 97: 302-307.

Kahneman D, Knetsch J, Thaler R. 1990. Experimental tests of the endowment effect and the Coase theorem.J Political Econ 98: $1325-1348$.

Krause J, Lalueza-Fox C, Orlando L, Enard W, Green RE, Burbano HA, Hublin JJ, Hänni C, Fortea J, de la Rasilla M, Bertranpetit J, Rosas A, Pääbo S. 2007. The derived FOXP2 variant of modern humans was shared with Neandertals. Curr Biol 17: 1908-1912.

Kuhn SL, Stiner MC. 2006. What's a mother to do? A hypothesis about the division of labor and modern human origins. Curr Anthropol 47: 953-980.

Negash A, Shackley MS, Alene M. 2006. Source provenance of obsidian artifacts from the Early Stone Age (ESA) site of Melka Konture, Ethiopia. J Archaeol Sci 33: 1647-1650.

Nelson RR, Winter SG. 1982. An evolutionary theory of economic change. Harvard University Press, Cambridge, MA.

Ofek H. 2001. Second nature: Economic origins of human evolution. Cambridge University Press, Cambridge.

Pagel M, Mace R. 2004. The cultural wealth of nations. Nature 428: $275-278$.

Powell A, Shennan S, Thomas MG. 2009. Late Pleistocene demography and the appearance of modern human behavior. Science 324: $1298-1301$.

Read LE. 1958. I, pencil. The Freeman, December 1958.

Ricardo D. 1817. On the principles of political economy and taxation. Murray, London.

Richerson PJ, Boyd R. 2005. Not by genes alone: How culture transformed human evolution. University of Chicago Press, Chicago.

Richerson PJ, Boyd R, Bettinger RL. 2009. Cultural innovations and demographic change. Hum Biol 81: 211-235.

Ridley M. 1993. The red queen: Sex and the evolution of human nature. Penguin, London.

Ridley M. 1996. The origins of virtue: Human instincts and the evolution of cooperation. Penguin, London.

Seabright P. 2005. The company of strangers: A natural history of economic life. Princeton University Press, Princeton, NJ.

Sharp L. 1974. Steel axes for Stone Age Australians. In Man in adaptation: The cultural present (ed. Y Cohen), pp. 116-127. Aldine, Chicago.

Simon J. 1996. The ultimate resource 2. Princeton University Press, Princeton, NJ.

Smith A. 1776. An inquiry into the nature and causes of the wealth of nations (facsimile edition). University of Chicago Press, Chicago.

Stringer C. 2006. Homo britannicus. Penguin, London.

Tishkoff SA, Reed FA, Ranciaro A, Voight BF, Babbitt CC, Silverman JS, Powell K, Mortensen HM, Hirbo JB, Osman $\mathrm{M}$, et al. 2007. Convergent adaptation of human lactase persistence in Africa and Europe. Nat Genet 39: 31-40.

Wrangham R. 2009. Catching fire: How cooking made us human. Perseus, Philadelphia. 


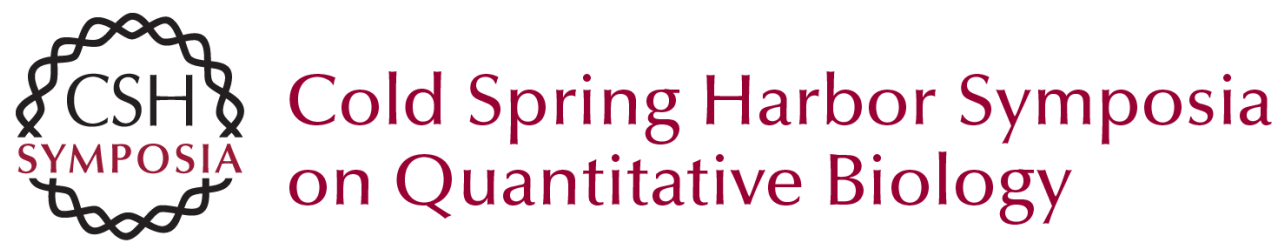

\section{When Ideas Have Sex: The Role of Exchange in Cultural Evolution}

M.W. Ridley

Cold Spring Harb Symp Quant Biol 2009 74: 443-448 originally published online September 23, 2009 Access the most recent version at doi:10.1101/sqb.2009.74.017

References This article cites 21 articles, 3 of which can be accessed free at: http://symposium.cshlp.org/content/74/443.full.html\#ref-list-1

License

Email Alerting Receive free email alerts when new articles cite this article - sign up in the box at the Service top right corner of the article or click here.

To subscribe to Cold Spring Harbor Symposia on Quantitative Biology go to:

http://symposium.cshlp.org/subscriptions 